Chairman: DR W. A. ALEXANDER, F.R.C.P.E., M.B., Ch.B., PRESIDENT OF THE ROYAL COLLEGE OF PHYSICIANS, EDINBURGIF

\title{
The Impact of Vitamin Research upon Medical Practice*
}

\author{
By V. P. Sydenstricker, Medical College of Georgia, Augusta, Georgia, U.S.A.
}

Vitamins usually are functional components of enzyme systems common to all forms of life from bacteria, possibly even viruses, to human beings. All life depends upon some type of respiration and upon the utilization of some sort of foodstuff to replace metabolic waste, maintain anabolic activity and ensure reproduction. These basic functions depend upon the activities of enzyme systems. My knowledge of biochemistry and physiology is much too meagre to warrant even an amateur attempt to present the whole picture. It seems very likely, however, that all vitamins are constituents, and probably the active fractions, of coenzymes necessary to all vital processes. There are wide species differences in requirements; many animals can synthesize some of the vitamins they require and harbour in their intestines bacteria that can synthesize more. This applies even to man: Largely, however, man and the higher animals are dependent upon vitamins or provitamins manufactured by plants. As a physician trained for internal medicine but dabbling occasionally in biochemistry and nutrition I shall try to summarize in a short space some of the more important things which increasing knowledge about vitamins has brought to clinical people during the past 40 years. Much of what I say will be historical and that I hope is proper.

\section{Early vitamin research}

Some sort of knowledge of the specific curative effects of liver and fresh milk and muscle meat and some fruits and vegetables for certain disorders has been prevalent since early times. There were perhaps more than whisperings of wisdom among the Egyptians who knew that fish livers were good for night-blindness. More than 3000 years ago the Chinese knew that the liver of almost any creature helped some forms of anaemia. American Indians four centuries ago, and no one knows how much longer, knew that infusion of spruce or pine needles cured the scurvy. Presently we are celebrating the first documented medical observation of the prevention and cure of a deficiency disease with a specific substance, now known to contain a vitamin, and this only 200 years ago. At about the same time it seems to have been well known among the Scandinavians, the British and the people of Labrador that cod-liver oil or just cod livers prevented and cured night-blindness

* The Second Sydney Watson Smith Lecture of the Royal College of Physicians, Edinburgh. 
and rickets. Somewhat earlier, in 1735 , Casal in Spain had recognized pellagra as a new disease and probably correctly attributed it to the introduction of maize from America.

After Lind (1753) and Casal there was a long hiatus in the story of the vitamins. Magendie (I8I6) fed animals on 'purified diets' and observed that they did not grow well and developed dryness and opacity of the cornea which we now call xerophthalmia. His experiments attracted considerable attention but not much long-term interest. However, in I 857 Livingstone in Africa observed changes in the eyes of ill-fed natives which he described as being similar to those described by Magendie. Lobo, and later Bitot, in South America found similar ocular lesions in slaves on the sugar plantations which they thought might be due to the monotonous diet those people used. The time then was about $\mathrm{I}_{5} 6_{5}$ and though xerophthalmia, Bitot's spots and night-blindness were well known in various parts of the world, they generally were attributed to what the diet contained rather than to what it lacked. Nineteenth-century investigators were busy with the basic aspects of nutrition and, while they learned much regarding caloric requirements and the utilization of protein, fat and carbohydrate, they remained mystified by the fact that calorically adequate 'purified diets' failed to sustain life.

Actually the concept of deficiency disease seems to have been suggested by William Prout in 1834 . Pereira ( 1843 ) some years later restated Prout's thesis that life could not be sustained upon a diet of purified protein, fat and carbohydrate and added the observation that 'natural foods' are necessary for life. He also noted that lemon juice, so curative for scurvy, did not owe its influence to the water, albumin, sugar or essential oil that it contained. Lunin ( $188 \mathrm{r}$ ) almost discovered the nutritive value of milk and von Bunge, discussing Lunin's investigations, suggested that milk might contain unknown substances necessary for health.

Takaki ( 1887 ) in a remarkable demonstration showed that beriberi could be prevented by the addition of meat, vegetables and condensed milk to the customary rice and fish diet of the ratings of the Japanese navy. He did not grasp the significance of this at the time but attributed the improvement just to a higher caloric intake of varied foods comparable to that in the rations of the British and German navies. The Dutch physiologist, Eijkman (1897), working in Batavia Io years later produced beriberi, or rather peripheral neuritis, in fowls by feeding them on polished rice and cured them by giving watery or alcoholic extracts of rice bran. This did not suggest to him a deficiency disease; he thought that the rice contained toxins and that the polishings contained a pharmacological antidote to them. Grijns (I9OI), 4 years later, correctly interpreted Eijkman's experiments suggesting that beriberi in birds and men was due to the lack of an essential substance not present in polished rice but abundant in the polishings. Pekelharing (1905), in Holland, and Hopkins (I906), at Cambridge, almost simultaneously observed that mice or rats fed on 'purified diets' failed to grow or live long. However, they observed that the addition of minute amounts of milk, not exceeding $4 \%$ of the diet, permitted growth and survival. Both suspected that some substance or substances present in infinitesimal amounts in milk and perhaps in other natural foods might 
be of paramount importance in nutrition. It was Hopkins who introduced the phrase 'accessory factors of the diet' in 1906 and by so doing stimulated a tremendous amount of thinking and investigation along the line of this new concept.

Holst \& Frölich (1907), attempting to produce beriberi in guinea-pigs with a diet of oats and bran, made the conies sick and almost immediately recognized that the sickness was scurvy and not beriberi. They suspected that the lack of a dietary factor might be at fault. They and others confirmed this suspicion but found that the factor was different from that lacking in beriberi. It was found in different types of food and was much more perishable. Shortly afterwards, Stepp (r909, 191 r), working in Germany, made a significant contribution by showing that fats were necessary for life. He even suspected that it was not so much the lipids themselves as unknown substances dissolved in them that were essential for the survival of his animals. At the same time Funk was working at the Lister Institute following up the investigations of Eijkman, Grijns and some of the early British workers on the nature of the antiberiberi substance in rice polishings. He did not isolate the pure substance but did prepare a highly effective concentrate and suggested that the pure substance might be a pyridine compound. Much more important than his potent rice-polish extract was the report on his work published in 1912 and 1913 (Funk, 1912-I3), in which he used the term 'vitamine' to designate the elusive antiberiberi factor. He put forth the radical hypothesis that beriberi, scurvy and pellagra were all deficiency diseases and that rickets and sprue possibly were in the same category.

During the same few years that Stepp and Funk were pursuing their research, Americans, stimulated by the ideas of Hopkins, were studying the effects of deficiencies of 'accessory factors of the diet'. Both McCollum \& Davis (1913) and Osborne \& Mendel (1913, 1914) demonstrated that diets containing butterfat, egg yolk or cod-liver oil supported normal growth in rats whereas those containing lard, olive oil or almond oil failed so to do. McCollum \& Davis (I9I3) discovered that an ether extract of the active natural fats contained the growth factor, and in $\mathrm{rgI}^{\prime} 3 \mathrm{McCollum}$ proposed the term 'fat soluble $A$ ' for the essential nutrient shortly to be called 'vitamin A'.

Although the nature of the 'accessory factors of the diet' was to remain obscure for a number of years, Hopkins had produced a fundamental idea, Funk a startling application of the idea to human disease as well as an intriguing name for the accessory factors. A lead was made toward the chemical composition of some of them and an alphabetical designation was initiated by McCollum. In the year I9I 3 the era of vitamin research was born. Not excepting the discovery of the bacteria and the whole pageant of infectious disease, perhaps no medical discovery has bred so much eagerness and enthusiasm for research. Here was an open field for the biochemist, the physiologist, the pharmacologist and the clinician. A little later the pathologist, the bacteriologist and the veterinarian were to join. In fact, every branch of science that has to do with that extraordinary mélange of effort which we call medicine was to become involved. Naturally there was much scepticism and many 
eminent, elderly, medical men went to their graves during the next two decades deploring the vagaries of 'mad scientists'.

From then on knowledge came rather rapidly, though its progress was hampered by imperfect understanding of deficiency diseases, crude techniques for research, and often by unfortunate choice of experimental animals. McCollum \& Davis ( $1915 a, b)$, investigating the nutritive value of individual foods, found that oats and rice, supplemented by all then known growth factors, were inadequate to support normal growth in rats. They postulated a 'water soluble B vitamine' which they thought might be identical with the antiberiberi factor of Funk. During these few years much research had gone on regarding scurvy. Drummond (I9I9) had postulated the existence of an antiscorbutic 'vitamin $C$ '. He, with many others, doubted Funk's hypothesis of the 'amine' nature of many of the essential nutrients and coined the word 'vitamin', suggesting that it might be used for all known and to be discovered essential nutrients without regard to their chemical structure. This was a time of great effort and much perplexity, with high authority clinging to ideas of an infectious or toxic aetiology for scurvy and pellagra. The matter of rickets was much complicated by the common knowledge that it could be cured by either cod-liver oil or sunlight. Actually much denseness was exhibited by some outstanding clinicians who attributed all the virtues of cod-liver oil to its high caloric value. During this same short period Goldberger, in America, performed the Rankin Farm experiment (Goldberger \& Wheeler, 1915) which initiated solution of the problem of pellagra, and Mellanby, in England, began his epochal experiments upon the production of rickets in animals. Almost the whole medical world was astir with a new and fruitful idea.

Up to now I have tried to give a brief summary of the early years of vitamin research. From now on it may be less confusing to follow the development of work upon individual vitamins. Many important phases of investigation and the names of a great many important investigators must be omitted because time permits mention of only the most outstanding.

\section{Vitamin $A$}

The story of vitamin A is very complicated. Early experimentors were concerned only with growth and development of experimental animals, usually rats. Goldschmidt (I9I5), in Hopkin's laboratory, observed keratomalacia in the rats eating Hopkins's purified diets. Two years later McCollum \& Simmonds (1917) described the same condition in rats on a more specifically 'A deficient diet', calling it xerophthalmia. Rather rapid recognition of more and more effects of vitamin A deficiency in animals and man developed. The situation at this time was clouded by the fact that cod-liver oil was usually used as the source of vitamin $A$ in experimental work. The existence in the oil of vitamin $D$ was unknown at this time. Some clarification came when Steenbock (I9I9) found that yellow vegetables were a good source of vitamin A. He extracted carotene from carrots and showed that it afforded excellent protection against vitamin A deficiency. Much argument, 
and even polemics, developed over the fact that carotene is deep yellow whereas cod-liver oil is almost colourless. Although von Euler (von Euler, von Euler \& Hellstrom, I928) and others confirmed Steenbock's observation, it was not until r 929 that the paradox was solved. Moore (1929a,b), at Cambridge, then showed that carotene is provitamin $A$ and is split into the vitamin in the body, probably in the liver.

While chemists strove to isolate and synthesize vitamin A, biochemists, physiologists and physicians were busy learning more about its relation to disease in animals and human beings. The task was greatly simplified by the discovery by McCollum, Simmonds, Becker \& Shipley (1922) of vitamin D. Fridericia \& Holm (1925) found that the amount of visual purple in the retina is diminished in avitaminosis $\mathrm{A}$ and that night-blindness is an early sign of deficiency in rats. This led to the use of the adaptometer for detection of early deficiency in human beings, a method which did not prove fruitful. Also in 1925, Wolbach and his group published the first of their many observations upon lesions of the skin, the respiratory epithelium and other tissues resulting from deficiency of vitamin A (Wolbach \& Howe, 1925). Almost simultaneously Mellanby (1926) and others described changes in the central nervous system of deficient dogs. Clinical observations from all over the world multiplied in the journals, and by 1935 a syndrome of dark dysadaptation, xerophthalmia, follicular hyperkeratosis of the skin and undue susceptibility to respiratory infections was widely accepted as 'avitaminosis A'. In the enthusiasm of clinical research many unrelated ailments often were included. During the 15 years ending in 1935 an extraordinary amount of work had been done on the carotene and vitamin A content of foods and the 'life cycle' of the vitamin was worked out. Chemists had been less fortunate in their efforts to isolate and synthesize the pure substance. Strangely the synthesis came before the isolation. Fuson \& Christ (1936) accomplished the synthesis. Holmes \& Corbet (1937) probably produced the first pure natural vitamin a year later.

Pursuing the work of Fridericia \& Holm (1925), Yudkin and others had reported the presence of vitamin $\mathrm{A}$, or a substance with similar properties, in the retinas of various species of animals. Wald (1935) and Hecht, in 1937, (Hecht, Chase \& Shlaer, 1937) demonstrated that the active visual purple of the retina is a compound of vitamin A and an unidentified protein. Hecht suggested that a portion of the vitamin A fraction might be used up or destroyed in a reaction by which bleached visual purple is regenerated so that continual supplies are necessary. The details of this reaction are still under investigation. The neurological manifestations of vitamin A deficiency in animals at first believed by Mellanby, McCollum and others to be due to specific neurotrophic properties, have since been shown by Mellanby, Wolbach and their associates to depend upon overgrowth of bones of the skull and spine with resulting pressure upon nerves. Research upon vitamin $A$ continues and we still are ignorant of many of its functions.

\section{Vitamin B group}

The research upon the vitamin B group is an epic itself. I shall try to abbreviate it as much as is consistent with even spotty continuity. Funk, among many who 
searched for the elusive 'anti-beriberi vitamine', extracted yeast as well as rice polishings and prepared a concentrate highly potent against fowl beriberi. Working further with this, he derived three fractions which he called substances $I, 2$ and nicotinic acid. Substance I was effective against fowl beriberi in doses of $3^{-4} \mathrm{mg}$, but I $\mathrm{mg}$ sufficed if it was supplemented by a few $\mathrm{mg}$ of nicotinic acid. Substance 2 was inert against beriberi and we may never know what it was (Funk, I9I6). This was in 1916 and it is tragic to remember that Funk had the key to the B group in his hand but failed to turn it. However, at that time the concept of multiple dietary deficiencies had not been developed.

During the following decade rice polishings, yeast and extracts of both came into general use for the prevention and cure of beriberi and an enormous effort went into the attempts to isolate the pure antineuritic substance. It seems likely that Jansen \& Donath (1926) were the first to succeed though Peters, at Oxford (Kinnersley \& Peters, 1928), and Windaus, in Germany had produced what later proved to be an identical compound. The year was 1926 and though it was another ro years before thiamine, as we have come to call vitamin $B_{1}$, was synthesized, much was learned regarding its functions and their application to clinical medicine. Notable were Cowgill's (1934) formula for thiamine requirements and the observations of Aalsameer \& Wenckebach (1929), Wenckebach (1928) and Weiss $\&$ Wilkins (1937) upon beriberi heart disease. The physiological basis for many, if not all, of the manifestations of thiamine deficiency was produced by Peters and his associates at Oxford who showed that thiamine is essential to carbohydrate metabolism at the lactate-pyruvate level, being necessary in the pyruvate-oxidase reaction.

\section{Thiamine}

In 1936 vitamin $B_{1}$ was synthesized by two teams of chemists working quite independently. The procedure of Williams \& Cline (1936) proved to be more economical, and since then thiamine has been almost as abundant and cheap as aspirin. A year later great light came into the thiamine problem when Lohmann \& Schuster ( 1937 ) isolated cocarboxylase and proved that it was dithiaminephosphate, a pyrophosphoric ester of thiamine. Later it was shown that cocarboxylase is the enzyme active in the Peters reaction. More recently at least three more enzymic processes concerned with the utilization of carbohydrate have been shown to depend upon the activity of cocarboxylase. Much of the fundamental research upon the thiamine enzyme has come from British university laboratories, notably those of Oxford and Cambridge. Gradually more and more is being learned regarding the physiological functions of thiamine. During the year past Siliprandi \& Navazio (I952) found that insulin is required for the synthesis of cocarboxylase in the body. If it is confirmed that insulin is involved in the phosphorylation of thiamine, some of the many existing problems of diabetes may be nearer solution. 
Nicotinic acid

The story of nicotinic acid is essentially that of pellagra. It must be said that a little more armchair research involving thoughtful perusal of Funk's early work might have saved years of effort and a great many lives. In I 912 the ThompsonMcFadden Pellagra Commission, after weighing all the available evidence, decided that pellagra must be an infectious disease. No other explanation for the explosive epidemics causing upward of 10,000 fatalities a year could be imagined. Goldberger, of the (U.S.A.) Public Health Service, was assigned to track down and isolate the infectious agent. He was a faithful public servant and exhausted the possibilities so far as infection might be concerned. His observations meantime convinced him that the disease was in some way related to diet. In 1915 he was permitted to carry out the Rankin Prison Farm experiment (Goldberger \& Wheeler, I9I5), the success of which convinced some, but not too many, of the experts. Further, to demonstrate the non-infectious nature of pellagra, Goldberger (I9I6) and fifteen of his associates inoculated themselves with the blood and swallowed the pharyngeal secretions, urine, faeces and desquamated skin of patients far gone with the disease. None of the group showed any ill effects. This was in 1916. During the same year Spencer noted the great similarity between blacktongue in dogs and pellagra in people. Shortly it was well established that blacktongue could be produced with the 'pellagra producing diet' and cured with meat, eggs and milk which had been shown to be curative in pellagra. With an experimental animal now available, it seemed that the work should go forward quite rapidly.

At this time Goldberger believed that the deficiency was of protein of good biological value and supported the maize theory of pellagra because zein, the major corn protein, is lacking in tryptophan and lysine. This idea was shared by British observers working in Egypt and became generally accepted. A great deal of investigation of the pellagra-preventive value of foods and of the curative properties of foods, concentrates and extracts went on during the ensuing to years, work which was very useful but which threw no light on aetiology. In I 920 Voegtlin had tried crude yeast extracts, potent against beriberi, in the treatment of pellagra with excellent results. He refined the extract and greatly increased its potency against beriberi but found the new preparation inert in pellagra and abandoned the experiment (Voegtlin, Neil \& Hunter, I920). This work evidently was overlooked because it was not until I925 that Goldberger \& Tanner (1925) tested yeast on dogs with blacktongue and secured dramatic cures. This observation was immediately applied to the treatment of pellagra with much success.

Goldberger, some years before, had abandoned the deficient-protein theory of the aetiology of pellagra in favour of the idea of a pellagra-preventive factor. Smith \& Hendrick (I926) found that heating yeast extracts of good 'vitamin B' content destroyed their antiberiberi activity but did not affect their curative value in blacktongue. Goldberger, Wheeler, Lillie \& Rogers (1928) quickly repeated these experiments, confirmed the results and went on to show that the heat-stable substance in autoclaved yeast and yeast extracts cured pellagra, but definitely was not 'vitamin B'. He called it the P-P factor. Yeast now became the universal 
cure and preventive; but for the desperately ill pellagrins still coming into our hospitals it was not good enough. Many could neither swallow nor retain the gramper-kilo-per-day of yeast or the equivalent amounts of yeast extracts necessary for cure. For them something better had to be found.

Voegtlin as early as I9I4 had prepared an extract of liver which he found helpful in pellagra, but the method was not practical (Voegtlin, I9r4). In I930 Goldberger and Sebrell reported the cure of blacktongue with a powdered crude liver extract (Goldberger \& Sebrell, I930). Soon it was found that this and commercially available concentrated aqueous liver extracts were highly effective in pellagra, but difficult for the seriously ill to take and retain. When injectable liver extracts became available, they were immediately given wide trial. It was found that crude extracts were effective but that the more refined extracts, which were most potent in pernicious anaemia, were useless in pellagra. A great deal of investigation of liver extracts and various fractions thereof went on during the early 1930's without gain. Then, in 1937 , the case of pellagra was broken quite suddenly by Elvehjem who, I suspect, may have read Funk's reports with more acumen than others. Immediately upon his report of the cure of blacktongue with nicotinic acid (Elvehjem, Madden, Strong \& Wooley, I937), his discovery was applied to pellagra with almost incredible success. The control of pellagra seemed assured.

Before nicotinic acid, or its amide, was found to be an essential nutrient, it was known that coenzymes I and II, otherwise known as diphosphopyridine nucleotide and triphosphopyridine nucleotide, are essential in the intermediate metabolism of carbohydrate. Both coenzymes depend upon their nicotinic-acid amide fraction for activity. Actually no less than five reactions in the metabolism of carbohydrate and fat have been shown to involve these compounds. It is supposed that the biochemical lesion in pellagra is due to failure of production of the coenzymes. Why this should produce the anatomical lesions of the disease remains unexplained. Another phase of the nicotinic-acid problem is the matter of its synthesis from tryptophan. This has been shown to be possible in various animals and in man. Current research upon this may bring us back to Goldberger's idea of the relation of tryptophan deficiency to pellagra.

\section{Riboflavin}

In the summer of 1938 a number of pellagrins who apparently had been cured with nicotinic acid and were on maintenance dosage seemed to relapse (Schmidt \& Sydenstricker, 1938). They developed sore tongues, fissures at the angles of the mouth, cracking and peeling of the lips, conjunctivitis and some a scaly, seborrheic dermatitis of the forehead, nasolabial folds and ears. Stannus (1912, I913), Fitzgerald (1932), Moore (1940) and others had described such a syndrome. Goldberger \& Wheeler (1920) encountered it and called it pellagra sine pellagra. Sebrell $\&$ Butler (1938) at the time were conducting an experiment with a riboflavin-deficient diet; they were consulted and they identified the syndrome as riboflavin deficiency 'uncovered' by treatment with nicotinic acid. Treatment with riboflavin cured the 
patients. Thus the early hypothesis of Goldberger \& Tanner (1925) that more than one factor might be lacking in pellagra was confirmed.

Before this there had been much confusion about riboflavin. Warburg \& Christian (1932) had isolated the 'yellow respiratory ferment' from yeast in 1932. In the following year Kuhn and his associates, attempting to isolate vitamin $\mathrm{B}_{2}$, had produced a substance identical with Warburg's yellow enzyme. Finding that it was essential for the nutrition of rats, they assumed that it was the P-P factor of Goldberger, or vitamin $B_{2}$ as it was generally called in Europe. This it definitely was not, and the name riboflavin was adopted in 1937. Like thiamine and nicotinic acid, riboflavin is a component of the active group in a number of oxidative enzyme systems, some of which are concerned with carbohydrate metabolism, others with much more subtle vital processes. Considering the great number of potent enzymes in which riboflavin is active, it is surprising that the manifestations of deficiency in the human subject are not more striking.

\section{Pyridoxin, pantothenic acid, biotin and folic acid}

During the decade 1930-40 there was intensive research upon many crystalline substances derived from yeast, liver and other sources; some had been known for many years, others just discovered. Many essential nutrients for bacteria and animals were found. Pyridoxin, pantothenic acid and biotin, in particular, proved to be essential to many forms of life and probably also for man although a deficiency state has never been proved for human subjects. It may be that these vitamins are so ubiquitous that no diet capable of sustaining life can be devoid of them. Mitchell, Snell \& Williams (194I) isolated from spinach a substance which they called 'folic acid', the chemical structure of which later invited the name 'pteroylglutamic acid'. Originally thought to be a growth factor for bacteria, it was found to be a potent haematopoietic factor for human beings which restores normal erythropoiesis in pernicious anaemia and stimulates the production and maturation of granulocytes in many conditions characterized by leukopenia. In fact, it seems requisite to the normal production of polymorphonuclear leukocytes. At first it was believed to be the extrinsic factor of Castle, but it soon was found that, while megaloblastic erythropoiesis was immediately replaced by normoblastic production of erythrocytes in pernicious anaemia under treatment with folic acid, the neurological changes of that disease progressed or even might appear during therapy. However, the whole syndrome of sprue usually is cured by it, as are the macrocytic anaemias of pregnancy and infancy and 'chronic malnutrition'. Folic acid is a growth, health and haematopoietic factor essential for many forms of life and probably is identical with the 'vitamin M' of Day, Langston \& Darby (1938). In conjugated form it is known to function in a variety of enzyme systems and is required for the synthesis of nucleic acids.

\section{Vitamin $B_{12}$}

After folic acid was found not to be the extrinsic factor, more intensive studies 
of liver extracts were resumed using more refined techniques. Almost simultaneously Smith (1948), in England, and Rickes, Brink, Koniuszy, Wood \& Folkers ( 1948 ) announced the recovery from liver extract of a crystalline cobalt-containing compound which showed extraordinary haematopoietic effects in pernicious anaemia. It was called vitamin $B_{12}$ by the American workers and later was given the name cyanocobalamin. This substance has a wide occurrence and is particularly abundant in the mother liquor of Streptomyces griseus fermentation. At the present time vitamin $B_{12}$ seems to fulfil all criteria for acceptance as the extrinsic factor of Castle, but much remains to be learned regarding it and closely related compounds.

\section{Vitamin $C$}

A. Szent-Györgyi, working at Cambridge in 1927 , isolated a substance from adrenal glands, oranges and cabbages which behaved in many ways like a sugar (Szent-Györgyi, I928). First he called it 'Ignose' because it baffled him; then, from further frustration, 'Godnose'. Finally having determined its structure, he called it hexuronic acid. Five years later C. Glenn King isolated pure vitamin C from natural sources and announced that it had all the characteristics of SzentGyörgyi's hexuronic acid (Waugh \& King, 1932). Within weeks Svirbely \& SzentGyörgyi (1932) reported that hexuronic acid cured scurvy in guinea-pigs and shortly confirmed the co-identity of hexuronic acid and vitamin C. Synthesis was accomplished within a year by Reichstein in Switzerland (Reichstein, Grüssner \& Oppenaur, I933) and Haworth and Hirst in England (Ault, Baird, Carrington, Haworth, Herbert, Hirst, Percival, Smith \& Stacey, 1933).

The biochemical functions of vitamin $\mathrm{C}$ remain obscure. It is a strong reducing agent and almost certainly is important in many hydrogen-transfer systems. In addition to its unexplained role in maintaining the integrity of intercellular cement substances, it evidently has important action in haematopoiesis and in the reaction of the body to stress. Perhaps the only complete experiment on the production of scurvy in a human being was that of Crandon, Lund \& Dill (1940) and it left very many problems unsolved.

\section{Vitamin $D$}

In r9rg Mellanby produced rickets in puppies with a diet and tested the curative properties of many substances, finding cod-liver oil far superior to any other (Mellanby, 19r8-19). Since the oil was known to contain vitamin A, it was natural for him to suppose that rickets was due to vitamin A deficiency. Shortly the situation was further clouded by a series of discoveries. Huldschinsky (I9I9) proved that the age-old belief that sunlight was a cure for rickets was well founded. It already was known that ultraviolet light was effective. Sherman \& Pappenheimer (I92 I) produced rickets with a low-phosphorus, high-calcium diet and the following year McCollum, Simmonds, Shipley \& Park (1922) showed that a high-phosphorus, low-calcium diet also was rachitogenic. In the same year, 1922, some clarification of the problem was afforded by the discovery of McCollum and his group that 
the vitamin A of cod-liver oil could be destroyed by oxidation. However, the oil retained its antirachitic properties (McCollum, Simmonds, Becker \& Shipley, I922). McCollum proposed the name vitamin D for the heat- and oxygen-stable substance.

Slowly and with considerable polemic vitamin D emerged as the antirachitic factor. In 1924 Hess \& Weinstock (1924) and Steenbock \& Black (1924) almost simultaneously discovered that ultraviolet irradiation of rachitogenic diets rendered them curative. It was found very shortly that only the lipid constituents of foods were activated by irradiation. After much investigation it was found that ergosterol and 7-dehydrocholesterol possess the greatest potency after irradiation. We buy irradiated ergosterol in the pharmacists' shops and the sun makes vitamin $D$ from 7 -dehydrocholesterol in our skins. Rickets still occurs in negro babies whose melanophores shield the deeper layers of their skins and in a decreasing number of white infants whose mothers neglect to give them the 'drops the doctor ordered'. The conquest of rickets seems assured.

\section{Vitamin $K$}

Henrick Dam, of Copenhagen, has long been interested in sterol metabolism. In 1929 he described a haemorrhagic disease of chicks maintained upon a special fat-free diet. The disease was characterized by great prolongation of the clotting time, which usually is associated with prothrombin deficiency. Having ruled out other causes for the prolonged clotting time, Dam suggested a Koagulationsvitamin deficiency which interferes with the synthesis of prothrombin in the liver (Dam, 1929). Although vitamin $\mathrm{K}$ was found to occur in many plants, it became evident that it was a product of metabolism in many species of bacteria and that the most important source is the intestinal flora. The chemical structure was soon determined and it was found that a number of related compounds exhibited vitamin $\mathrm{K}$ activity. Absorption of vitamin $\mathrm{K}$ from the bowel depends upon the presence of fat and bile, and the synthesis of prothrombin in the presence of vitamin $\mathrm{K}$ depends upon reasonably normal function of the cells of the liver. These observations threw much light upon the matter of prothrombin deficiency which is well known to occur in obstructive jaundice and in severe hepatocellular disease. Vitamin $\mathrm{K}$ and its compounds are the first effective remedy for haemorrhage due to prolonged biliary obstruction. If damage to liver cells, from any cause, is great, the vitamin cannot improve prothrombin levels.

\section{Antivitamins}

No discussion of vitamins in relation to medical research would be complete without reference to vitamin antagonists. A number of such substances exist which are useful in research upon deficiency diseases, upon cancer, leukaemias and lymphomas. Most useful are the vitamin $\mathrm{K}$ antagonists used in treatment of thromboembolic disease and for the destruction of vermin. The activity of an antivitamin usually depends upon such close structural similarity to the vitamin 
it 'antagonizes' that it is incorporated into the enzyme system in which the vitamin functions, inactivating the compound. As knowledge of these substances increases, they may become as helpful in the control of certain metabolic and malignant diseases as are the vitamins in deficiency diseases.

\section{Vitamin therapy}

In the application of vitamin research to the practice of medicine it is of prime importance to stress the multiple nature of deficiency states. Whether dealing with such well-defined disease syndromes as rickets, scurvy, beriberi, pellagra and kwashiorkor or with those presenting solitary symptoms such as night-blindness or retrobulbar neuritis it is most unlikely that an isolated avitaminosis is the cause. A diet sufficiently inadequate to produce clinical symptoms is usually if not always lacking in several vitamins and in protein, fat, iron and calcium as well. The fact that the presenting symptoms and signs of beriberi can be cured with thiamine or those of scurvy with ascorbic acid does not invalidate this statement. The significance of Funk's early observation that a little nicotinic acid enabled him to cure fowl beriberi with greatly reduced amounts of antiberiberi substance was not appreciated at the time. Later when therapy with nicotinic acid exposed the riboflavin deficiency in pellagra we were better prepared to accept the concept of multiple deficiency states. The superiority of Marmite and of aqueous extracts of liver over mixtures of crystalline vitamins in a number of nutritional disorders makes it probable that still unknown factors are present in such natural sources, which are in themselves necessary to health or to the utilization of the things about which we do know.

The importance of iron and protein must be emphasized. Anaemia is common to almost all nutritional diseases and at one time was considered due to specific deficiency of the various vitamins. It has become apparent that in human disease lack of iron and protein in the diet is largely the cause.

There are rather definite indications for the use of vitamins. In the presence of endemic disease such as pellagra, beriberi, scurvy or rickets the specific vitamins in therapeutic amounts and in appropriate mixtures should be employed until such a time as adequate intake and assimilation of proper food can be assured. If no sources of a satisfactory diet exist then continuous supplementation of an inadequate diet must be undertaken. When dealing with an isolated example of deficiency disease the same principles apply. The patient should be given adequate 'specific' therapy with all supportive measures necessary to enable him to use the natural sources of vitamins as soon as possible. If some ineradicable cause for failure of adequate intake, absorption or assimilation exists then supplementation may have to be continued indefinitely.

In the same vein vitamins must be added to inadequate diets deliberately prescribed for the management of certain diseases, notably those used in hypertension, peptic ulcer and obesity. Occasional patients having had resection of massive segments of the gastrointestinal tract will need large supplements to compensate for faulty absorption. Some individuals require predigested protein as well. In 
patients chronically ill who must be subjected to surgery, preparation for operation involves the use of vitamins. This applies particularly to those with peptic ulcer, carcinoma of stomach or bowel and hyperthyroidism.

Healthy people eating a normal diet do not need added vitamins, despite the claims one reads and hears. Vitamins will not cure the ailments of the psychoneurotic or the inertia and insomnia of the depressed. Neither are vitamins a pick-me-up for the tired and hungry. Pills in no way can replace food and as placebos vitamins are extraordinarily expensive.

The impact of the vitamins upon research has been tremendous, and upon the practice of medicine in many respects revolutionary. Old ideas of vague 'toxins' and 'obscure infections' have happily been abandoned in favour of rather definitive knowledge of the aetiology of some of the worst scourges of man. Enthusiasm has led to many errors and to some false premises, but overall the gain has been great. Much of what we know remains for research to develop. The impact of the vitamins is far from spent.

\section{REFERENCES}

Aalsameer, W. C. \& Wenckebach, K. F. (1929). Wien. Arch. inn. Med. 16, 193.

Ault, R. G., Baird, D. K., Carrington, H. C., Haworth, W. N., Herbert, R., Hirst, E. L., Percival, E. G. V., Smith, F. \& Stacey, M. (1933). F. chem. Soc. p. I4Ig.

Cowgill, G. R. (1934). The Vitamin B Requirement of Man. Yale: University Press.

Crandon, J. H., Lund, C. C. \& Dill, D. B. (r940). New Engl. F. Med. 223, 353.

Dam, H. (1929). Biochem. Z. 215, 475.

Day, P. L., Langston, W. C. \& Darby, W. J. (1938). Proc. Soc. exp. Biol., N.Y., 38, 860.

Drummond, J. C. (1919). Biochem. F. 13, 77.

Eijkman, C. (1897). Virchow's Arch. r49, 187.

Elvehjem, C. A., Madden, R. J., Strong, F. M. \& Wooley, D. M. (1937). Y. Amer. chem. Sor, 59, I 767.

Fitzgerald, G. H. (1932). Indian med. Gaz. 47, 557.

Fridericia, L. S. \& Holm, E. (1925). Amer. F. Physiol. 73, 63.

Funk, C. (1912-13). F. Physiol. 45, 489 .

Funk, C. (1916). Biochem. Bull. 5, I.

Fuson, R. C. \& Christ, R. E. (1936). Science, 84, 294.

Goldberger, J. (1916). Publ. Hlth Rep., Wash., 31, 3 I 59.

Goldberger, J. \& Sebrell, W. H. (1930). Publ. Hlth Rep., Wash., 45, 3064.

Goldberger, J. \& Tanner, W. F. (1925). Publ. Hlth Rep., Wash., 40, 54.

Goldberger, J. \& Wheeler, G. A. (I9I5). Publ. Hlth Rep., Wash., 30, 3336.

Goldberger, J. \& Wheeler, G. A. (1920). Bull. U.S. hyg. Lab. no. 120, p. 7.

Goldberger, J., Wheeler, G. A., Lillie, R. D. \& Rogers, I. M. (1928). Publ. Hlth Rep., Wash., 43, 657.

Goldschmidt, M. (1915). Graefes Arch. Ophthal. 90, 345.

Grijns, C. (I901). Geneesk. Tijdschr. Ned.-ind. 4I, 3 .

Hecht, S., Chase, A. M. \& Shlaer, S. (1937). Science, $85,567$.

Hess, A. F. \& Weinstock, M. (1924). F. biol. Chem. 62, 301.

Holmes, H. N. \& Corbet, R. E. (1937). Science, 85, 103.

Holst, A. \& Frölich, T. (1907). F. Hyg., Camb., 7, 634.

Hopkins, F. G. (I906). Analyst, 3r, 385 .

Huldschinsky, K. (1919). Dtsch, med. Wschr. 45, 712.

Jansen, B. C. P. \& Donath, W. F. (1926). Proc. Acad. Sci. Amst. 29, 1390.

Kinnersley, H. W. \& Peters, R. A. (1928). Biochem. F. 22, 419.

Lind, J. (1753). A Treatise of the Scurvy. Edinburgh: Sands, Murray \& Cochran for A. Kincaic and A. Donaldson.

Lohmann, K. \& Schuster, P. (1937). Naturwissenschaften, 25, 26.

Lunin, N. (1881). Hoppe-Seyl. Z. 5, 31 .

McCollum, E. V. \& Davis, M. (1913). F. biol. Chem. 15, I67.

McCollum, E. V. \& Davis, M. (I9I5a). F. biol. Chem, 21, 6 I 5 .

McCollum, E. V. \& Davis, M. (1915b). F. biol. Chem. 23, i81.

McCollum, E. V. \& Simmonds, N. (igi7). F. biol. Chem. 32, i 8 I. 
McCollum, E. V., Simmonds, N., Becker, J. E. \& Shipley, P. G. (r922). F. biol. Chem. 53, 293.

McCollum, E. V., Simmonds, N. C., Shipley, P. G. \& Park, E. A. (1922). Amer. F. Hyg. I, 512.

Magendie, F. (1816). Ann. Chim. (Phys.) 3, 66.

Mellanby, E. (1918-19). F. Physiol. 52, xi.

Mellanby, E. (1926). F. Physiol. 6r, xxiv.

Mitchell, H. K., Snell, E. E. \& Williams, R. J. (1945). F. Amer. chem. Soc. 63, 2284.

Moore, D. F. (I940). F. trop. Med. (Hyg.) 43, 190.

Moore, T. (1929a). Biochem. 7. 23, 803.

Moore, T. (1929b). Biochem. F. 23, 1267.

Osborne, T. B. \& Mendel, L. B. (1913). F. biol. Chem. 15, 3 I I.

Osborne, T. B. \& Mendell, L. B. (I9I4). F. biol. Chem. 16, 423 .

Pekelharing, C. A. (1905). Ned. Tijdschr. Geneesk. 2, II I.

Pereira (1843). A Treatise on Food and Diet. New York: J. and H. G. Langley.

Reichstein, T., Grüssner, A. \& Oppenaur, R. (1933). Nature, Lond., 132, 280.

Rickes, E. L., Brink, N. G., Koniuszy, F. R., Wood, T. R. \& Folkers, K. (1948). Science ro7, 396.

Schmidt, H. L. \& Sydenstricker, V. P. (1938). F. Amer. med. Ass. 110, 2065.

Sebrell, W. H. \& Butler, R. E. (1938). Publ. Hlth Rep., Wash., 53, 2282.

Sherman, H. C. \& Pappenheimer, A. M. (1921). 7. exp. Med. 34, 189.

Siliprandi, N. \& Navazio, F. (1952). Acta med. scand. 142, 147.

Smith, E. L. (1948). Nature, Lond., 16r, 638.

Smith, M. I. \& Hendrick, E. G. (1926). Publ. Hlth Rep., Wash., 42, 201.

Stannus, H. S. (1912). Trans. R. Soc. trop. Med. Hyg. 5, 112.

Stannus, H. S. (1913). Trans. R. Soc. trop. Med. Hyg. 7, 32.

Steenbock, H. (I9I9). Science, 50, 352.

Steenbock, H. \& Black, A. (r924). Ұ. biol. Chem. 6r, 405.

Stepp, W. (1909). Biochem. Z. 22, 452.

Stepp, W. (1911). Z. Biol. 57, 135 .

Svirbely, J. L. \& Szent-Györgyi, A. (1932). Nature, Lond., 129, 576.

Sydenstricker, V. P., Geeslin, L. E., Templeton, C. M. \& Weaver, J. W. (1939). F. Amer. med. Ass. $\mathbf{r} 3, \mathrm{r} 697$.

Sydenstricker, V. P., Sebrell, W. H., Cleckley, H. M. \& Kruse, H. D. (I940). F. Amer. med. Ass. Ir4, 2437.

Szent-Györgyi, A. (1928). Biochem. F. 22, 1387 .

Takaki, K. ( (1887). Lancet, ii, 86.

Voegtlin, C. (I914). Personal Communication.

Voegtlin, C., Neil, M. A. \& Hunter, A. (1920). Bull. U.S. hyg. Lab. no. 116.

von Euler, B., von Euler, H. \& Hellstrom, H. (r928). Biochem. Z. 203, 370.

Wald, G. (1935). Y. gen. Physiol. 18, 905.

Warburg, O. \& Christian, W. (r932). Naturwissenschaften, 20, 688.

Waugh, W. A. \& King, C. G. (1932). F. biol. Chem. 97, 325.

Wenkebach, K.'F. (1928), Lancet, ii, 265.

Weiss, S. \& Wilkins, R. W. (1937). Ann. intern. Med. Ir, ro4.

Williams, R. R. \& Cline, J. K. (1936). F. Amer. chem. Soc. 58, 1504.

Wolbach, S. B. \& Howe, P. R. (r925). F. exp. Med. 42, 753. 